\title{
The assessment of correctness of engine adaptation for alternative LPG fueling based on full load engine characteristics of performance
}

\begin{abstract}
The paper presents a set of full load engine characteristics of gasoline and LPG fueled engines. The vehicles were divided into groups according to the type of LPG fueling system. The purpose of the research was to show and assess the differences between torque values as a function of engine speed. Statistics of the distribution of differences were created, based on which the conclusions were formulated. The results of the analysis can constitute a basis for on-road calculations for vehicles fitted with dual fueling system.
\end{abstract}

Key words: internal-combustion engine, research, LPG fueling, full load engine characteristics

\section{Ocena poprawności adaptacji silników do zasilania alternatywnego LPG na podstawie charakterystyk prędkościowych pelniej mocy}

\begin{abstract}
$W$ artykule przedstawiono zestawienie charakterystyk petnej mocy silników zasilanych benzyna i LPG. Pojazdy podzielono na grupy stosownie do rodzaju gazowego uktadu zasilania. Badania miały na celu wykazanie i ocenę różnic $w$ wartościach momentu obrotowego w funkcji prędkości obrotowej. Opracowano statystykę rozkładu różnic, na podstawie której wyciagnięto wnioski. Wyniki analizy moga postużý́ jako podstawa do obliczeń trakcyjnych pojazdu z dwupaliwowym uktadem zasilania.
\end{abstract}

Słowa kluczowe: silnik spalinowy, badania, zasilanie LPG, charakterystyka prędkościowa petnej mocy

\section{Introduction}

For the assessment of alternative fuel application in transport, experimental research is continually performed and simulation models are developed. For LPG fueling, a reduction of $\mathrm{HC}$ and $\mathrm{CO}$ ( $65 \%$ and $50 \%$ respectively) is indicated at an insignificant degradation of the overall efficiency as compared to gasoline fueling $[4,16]$. The successful application of this type of fuel, however, is mostly determined by its price. Modern designs, in which direct injection is the most common solution, can be alternatively fueled applying two methods - by LPG injection in the volatile phase via additional injectors or by the original gasoline injectors injecting liquid LPG. In the first case, with the additional LPG injection system, the emission heavily depends on the LPG percentage in the composition of combustible mixture because gasoline injectors inject small doses for cooling purposes. It is also possible to adjust the LPG share in the combustible mixture. The best environment related effects were achieved at a 100\% LPG composition [6]. The lack of gasoline injection, however, can cause injector overheating resulting in its damage. In the second case, the alternative fueling system is simpli-fied. It requires an LPG tank with an additional pump and a distributor controlling the selection of the type of fuel. It is not necessary to interfere with the injector control system (except the fuel pressure sensor or engine fueling rate sensor (i.e. accelerator pedal sensor or throttle position sensor).

Many publications have shown good applicability of LPG in vehicle engines $[26,27]$. The LPG fueling was proven effective at low temperatures $[3,10]$. The publications have drawn attention to the problem of LPG flow in the fuel rail

\section{Wprowadzenie}

W celu oceny stosowalności paliw alternatywnych w środkach transportu prowadzi się wiele badań doświadczalnych i opracowuje modele symulacyjne. Przy zasilaniu LPG stwierdzono redukcję emisji $\mathrm{HC}$ i CO (odpowiednio o $65 \%$ i $50 \%$ ), przy nieznacznym zmniejszeniu sprawności ogólnej względem zasilania benzynowego $[4,16]$. Jednak stosowanie tego rodzaju paliwa ogranicza przede wszystkim jego cena. Współczesne konstrukcje, w których dominuje wtrysk bezpośredni mogą być zasilane alternatywnie LPG dwoma sposobami: pierwszy - wtrysk LPG w fazie lotnej dodatkowymi wtryskiwaczami, drugi - wykorzystanie oryginalnych wtryskiwaczy benzynowych do wtrysku LPG ciekłego. W pierwszym sposobie, przy dodatkowym układzie wtryskowym LPG, emisja w znacznym stopniu zależy od procentowego udziału LPG w mieszaninie palnej, gdyż wtryskiwacze benzynowe wtryskują niewielkie dawki celem schłodzenia. Możliwa jest również regulacja udziału LPG w mieszaninie palnej. Najlepsze efekty w aspekcie ekologicznym osiągnięto przy $100 \%$ LPG [6], jednak brak wtrysku benzyny może spowodować przegrzanie wtryskiwaczy $\mathrm{i}$ w efekcie ich uszkodzenie. W drugim sposobie układ zasilania alternatywnego jest uproszczony, wymaga montażu zbiornika LPG z dodatkową pompą i rozdzielacza sterującego rodzajem paliwa. Nie jest konieczne ingerowanie w układ sterowania wtryskiwaczami, a jedynie w czujnik ciśnienia paliwa, lub czujnik stopnia zasilania silnika (tj. czujnik pedału przyspiesznika, lub czujnik obrotu listka przepustnicy).

Wiele prac wykazało stosowalność LPG w silnikach samochodowych [26, 27], z pozytywnym skutkiem wery- 
$[5,11,20]$. The authors' research has resulted in developing control algorithms of such systems [7, 23]. The basis for correct operation of each fueling system is the fuel quality, which, in the case of gasoline, is regulated by legislation [13] As for the case of LPG, it is not as clear. Corporate average fuel consumption standard is a significant tool in the policy to lower unit fuel consumption level. The legislation related to engine fuels allows special treatment of alternative fuel vehicles when calculating their fuel consumption to ensure the manufacturers' possibility to increase the production of fuel [14].

The research methods applied to analyze the injection process (both gasoline and LPG) are diverse. The observations focus on the injected LPG $[17,19]$ subsequently compared with the injection of gasoline (the pulsations occurring in the fuel rail are measured) [17]. The application of heat flow sensors enables designating the location and the level of the fuel hit upon the injection [21]. Laser diffraction techniques and laser exciting fluorescence also finds application in the fuel spray analysis $[1,2,9,15,18,31]$.

The research mainly focuses on brand new elements or systems. Simulation methods provide an image of an idealized process. Hence, the necessity occurs to test engines as a whole in different configurations. At this point, the significant aspect is to compare the engines fitted with different fueling systems at different degree of wear.

Important information can be delivered by wide-open throttle characteristics of engines fitted with traditional and alternative fueling systems. The speed characteristics at $100 \%$ power determines the maximum load range of a unit. By juxtaposing two engine characteristics against each other (of the engine already adapted for alternative fueling - fitting of required equipment: mixer or injectors), the differ-ences in torque can be determined, the distribution of which will
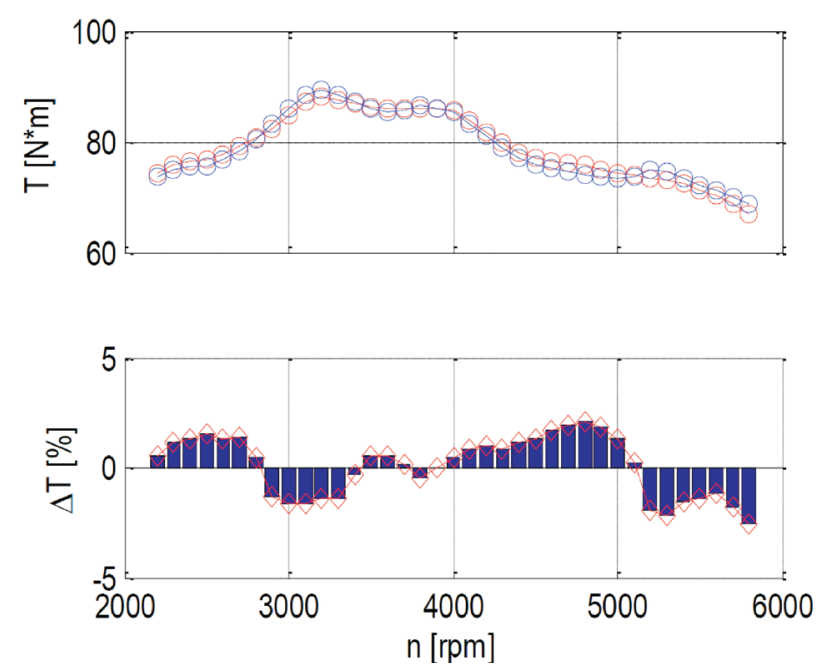

Fig. 1. Full load engine characteristics and displacement values of torque at both power systems - Skoda Fabia 1.4 MPi, alternative LPG IV generation (red - gasoline, blue - LPG)

Rys. 1. Charakterystyka petnej mocy silnika oraz wartości odchyłek momentu obrotowego przy obu uktadach zasilania - Skoda Fabia 1.4 MPi, alternatywnie LPG IV generacji (czerwony - benzyna, niebieski-LPG) fikowano zasilanie LPG w niskich temperaturach [3, 10]. Uwagę poświęcano problemowi przepływu LPG w szynie paliwowej $[5,11,20]$. Badania dotyczyły również algorytmów kontroli i płynnego sterowania tego typu układami zasilania [7, 23]. Podstawą poprawnego działania każdego układu zasilania jest jakość paliwa, co w odniesieniu do benzyny jest regulowane przepisami [13], a dla LPG nie jest to już tak jednoznaczne. Korporacyjna średnia norma zużycia paliwa jest ważnym narzędziem dotyczącym obniżenia poziomu jednostkowego zużycia paliwa. Ustawa o paliwach silnikowych umożliwia specjalne traktowanie pojazdów przy obliczaniu zużycia paliwa alternatywnego, tak aby zapewnić producentom możliwość zwiększenia produkcji paliwa [14].

Metody badawcze wykorzystywane do analizy procesu wtrysku zarówno benzyny, jak i LPG są zróżnicowane. Prowadzone są obserwacje strugi wtryśniętego LPG [17, 19] i porównywanie z wtryskiem benzyny, jak też pulsacje w szynie paliwowej [17]. Stosowanie czujników strumienia ciepła umożliwia wyznaczenie lokalizacji i poziomu uderzenia paliwa po wtryśnięciu [21]. Techniki dyfrakcji laserowej i fluorescencji wzbudzanej laserowo znalazły zastosowanie $\mathrm{w}$ analizie rozpylania paliwa $[1,2,9,15,18,31]$.

Prowadzone prace badawcze w znacznym stopniu dotyczą fabrycznie nowych elementów, czy układów. Badania symulacyjne dają obraz wyidealizowanego procesu, dlatego pojawia się konieczność badania silnika jako całości w różnych konfiguracjach układów zasilania. Ważnym aspektem w tym miejscu jest zestawienie silników dotyczących różnych układów zasilania w różnym stopniu zużycia eksploatacyjnego.

Istotnych informacji mogą dostarczyć charakterystyki zewnętrzne silników z klasycznymi i alternatywnymi układami zasilania. Charakterystyka prędkościowa przy 100\% zasilania wyznacza maksymalny zakres obciążalności jednostki napędowej. Zestawiając ze sobą dwie charakterystyki silnika, który jest już po adaptacji do zasilania alternatywnego (montaż wymaganego wyposażenia - mieszalnik lub wtryskiwacze itd.), można wyznaczyć różnice w wartościach momentu obrotowego, których rozkład umożliwi wnioskowanie o poprawności adaptacji silnika do alternatywnego zasilania (rys. 1).

Oceny adaptacji można dokonać na podstawie wskazań pokładowych systemów diagnostycznych [25] lub maksymalnych wartości różnic mocy i momentu obrotowego na charakterystyce zewnętrznej [26, 27]. W opracowaniu [28] wnioskowano o wartościach współczynników zależności Leidemana przy różnych układach zasilania. Innowacyjną metodę oceny funkcjonalnej silnika przedstawiono w pracy [29], gdzie wprowadzono nowy parametr operacyjny, jakim jest zapas ruchu.

\section{Procedury badawcze}

\subsection{Obiekty badań}

Obiektami badań były pojazdy o zróżnicowanych parametrach technicznych i stopniu zużycia eksploatacyjnego. Bazę wyników tworzono od 2004 roku w Laboratorium 
allow conclusions about the correctness of engine adaptation for alternative fueling (Fig. 1).

The adaptation assessment can be performed based on the indications of on-board diagnostics systems [25] or the differences in the maximum values of torque and power based on full load engine characteristics [26, 27]. In [28] Leidemann's dependency coefficients for various fueling systems have been given. The innovative method of functional assessment of an engine has been shown in [29] where a new operational parameter was introduced - the motion reserve.

\section{Material and methods}

\subsection{Subject of the research}

The research objects were vehicles of different degree of wear and different technical parameters. The database of results has been continually developed since 2004 at the Vehicle Laboratory of the Faculty of Mechanical Engineering at the Bialystok University of Technology. The research continued during didactic classes, scientific activities or promotional events.

The assignment of vehicles to specific research groups was performed based on the type of alternative fueling system:

- I generation LPG - 14 units,

- II generation LPG - 32 units,

- IV generation LPG - 40 units.

From the database, in which over 1000 measurements are stored, only part is related to full load engine characteristics, determined for traditional and LPG fueling systems. A total of 86 volatile phase LPG fueled vehicles were selected constituting the basis for statistical analysis.

\subsection{Research methodology}

LPS 3000 MAHA chassis dynamometer was used in the research (Fig. 2, tab. 1) enabling a determination of the full power speed characteristics.

Each time, before measurement, each engine was set to its nominal operating conditions (coolant and engine oil temperature at minimum $80^{\circ} \mathrm{C}$ ) to ensure LPG evaporation.

The measurement of the external indicators on the $\mathrm{dy}$ namometer was performed using the load balancing method while maintaining constant acceleration. The measurements
Pojazdów Samochodowych Wydziału Mechanicznego Politechniki Białostockiej. Badania przeprowadzano w ramach zajęć dydaktycznych, badań naukowych czy imprez promocyjnych.

Zaszeregowania pojazdów do poszczególnych grup badawczych dokonano na podstawie rodzaju alternatywnego układu zasilania i dlatego liczebności określono na poziomie:

- I generacja LPG - 14 egz.

- II generacja LPG - 32 egz.

- IV generacja LPG - 40 egz.

Z bazy, w której znajduje się ponad 1000 pomiarów jedynie część dotyczy charakterystyk pełnej mocy wyznaczanych przy zasilaniu klasycznym i LPG. Wyodrębniono 86 pojazdów zasilanych alternatywnie LPG w fazie lotnej, które stanowiły podstawę do analizy statystycznej.

Table 1. Basic technical data of the Maha LPS 3000 dynamometer (Maha) Tabela 1. Dane techniczne hamowni Maha LPS 3000 (Maha)

\begin{tabular}{|c|c|c|}
\hline $\begin{array}{l}\text { Parameter/ } \\
\text { parametr }\end{array}$ & $\begin{array}{c}\text { Unit/ } \\
\text { jednostka }\end{array}$ & $\begin{array}{l}\text { Values/ } \\
\text { wartość }\end{array}$ \\
\hline \multicolumn{3}{|c|}{ Roller set (Typ) R100/1 } \\
\hline Axle load/nacisk na rolki & $\mathrm{t}$ & 2.5 \\
\hline Length/dlugość & $\mathrm{mm}$ & 3345 \\
\hline Width/szerokość & $\mathrm{mm}$ & 1100 \\
\hline Height/wysokość & $\mathrm{mm}$ & 625 \\
\hline Weight/masa & $\mathrm{kg}$ & approx. 1200 \\
\hline Roller length/dtugość rolki & $\mathrm{mm}$ & 750 \\
\hline Track min./koło - min & $\mathrm{mm}$ & 800 \\
\hline Track max./koło $-\max$ & $\mathrm{mm}$ & 2300 \\
\hline Roller diameter/średnica rolki & $\mathrm{mm}$ & 318 \\
\hline \multicolumn{3}{|c|}{ Display range/zakres pomiaru } \\
\hline Test speed/prędkość badania & $\mathrm{km} / \mathrm{h}$ & $\max .250$ \\
\hline Wheel power/moc na kołach & $\mathrm{kW}$ & $\max .260$ \\
\hline Traction/siła napędowa & $\mathrm{kN}$ & $\max .6$ \\
\hline $\mathrm{RPM} /$ prędkość obr. silnika & $\mathrm{rot} / \mathrm{min}$. & $0-10000$ \\
\hline $\begin{array}{l}\text { Measurement accuracy of measur. } \\
\text { value/doktadność }\end{array}$ & $\%$ & \pm 2 \\
\hline
\end{tabular}
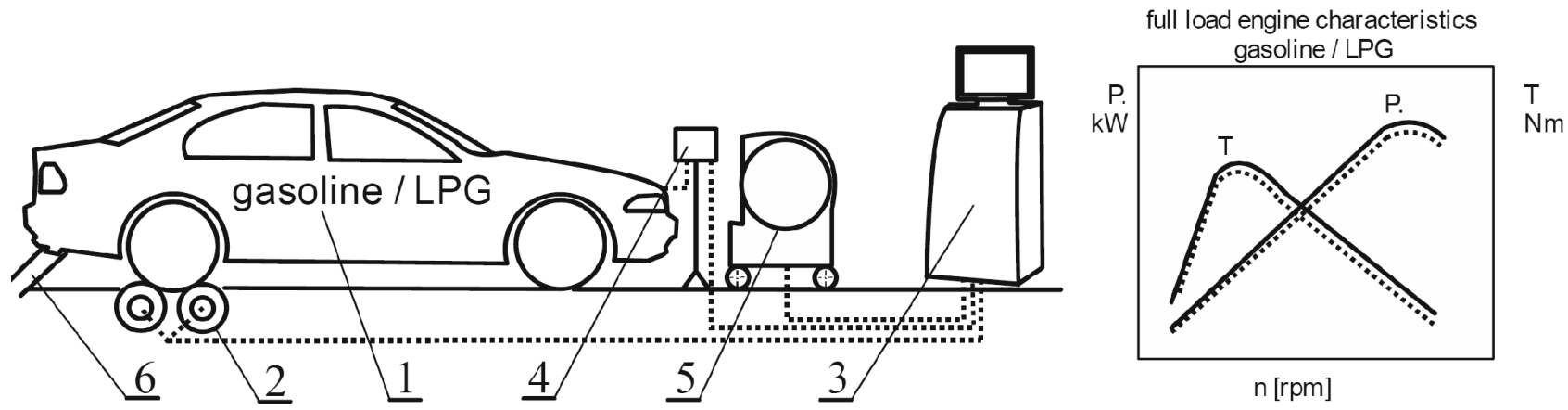

Fig. 2. Test stand: 1 - tested vehicle, 2 - roller type chassis dynamometer with eddy-current brake, 3 - dynamometer control system, 4 - vehicle signals connector box, 5 - fan, 6 - exhaust gas extractor

Rys. 2. Stanowisko badawcze: 1 - badany pojazd, 2 - hamownia podwoziowa z hamulcem elektrowirowym, 3 - układ sterowania hamownia, 4 - panel podłaczeń parametrów pojazdu, 5 - wentylator, 6 - odciag spalin 
were not repeated because several trials have shown that the difference in the measuring results of the same engine did not exceed $1 \%$.

\section{Results and discussion}

The measurement results were subjected to analysis by comparing both fueling systems in terms of torque values at a $100 \%$ fueling rate. To automate the data processing, the author's own calculating application was created in the MatlabSimulink environment - Guide toolbox [12, 22, 24, 30].

The software, based on the data loaded from a 'txt' file of each of the tested engines, determined the shape of the engine full load characteristics and the differences in torque $[\%]$ in relation to the dimensionless engine speed (Fig. 3). The author decided to render the engine speed dimensionless to unify the reference scale, allowing for the fact that fueling units can work at different operating speed ranges.

Additionally, the maximum power, torque as well as engine flexibility and torque reserve were determined.

In the next step, the given results were subjected to statistical analysis, in which the basic coefficients were determined, i.e.:

- arithmetic average:

$$
\bar{x}=\frac{\mathbf{X}_{1}+\mathbf{X}_{2}+\ldots+\mathbf{X}_{\mathrm{n}}}{\mathrm{n}}
$$

- estimator of standard deviation:

$$
s_{b}=\sqrt{\frac{1}{n-1} \cdot \sum_{i=1}^{n}\left(x_{i}-\bar{x}\right)^{2}}
$$

- bias:

$$
A_{d}=\frac{n}{(n-1) \cdot(n-2)} \cdot \sum_{i=1}^{n}\left(\frac{x_{i}-\bar{x}}{s}\right)^{3}
$$

- kurtosis/kurtozę:

$$
\begin{aligned}
K= & \left\{\frac{n \cdot(n+1)}{(n-1) \cdot(n-2) \cdot(n-3)} \cdot \sum_{i=1}^{n}\left(\frac{x_{i}-\bar{x}}{s}\right)^{4}\right\} \\
& -\frac{3 \cdot(n-1)^{2}}{(n-2) \cdot(n-3)}
\end{aligned}
$$

Using Guide toolbox, another software was created to determine the statistics of torque deviation distribution by using the test option in Matlab-Simulink (Fig. 4). As an effect, aside from the parameters described by dependencies (1-4), the following were determined: the probability of average values equality, range excess and confidence level at which the hypothesis about average values equality would not be rejected.

In Table 2 the results of torque deviation statistical analysis have been shown for both fueling types in different research groups.

The greatest differences in torque deviations have been observed in the I generation LPG system $-6.3 \%$ on average.

\subsection{Metodyka badań}

W badaniach wykorzystano hamownię podwoziową LPS 3000 MAHA (rys. 2, tab. 1), przy użyciu której wyznaczano charakterystyki prędkościowe pełnej mocy.

Każdorazowo przed pomiarem doprowadzano silnik do nominalnych warunków pracy (temperatura płynu chłodzącego i oleju silnikowego min. $80{ }^{\circ} \mathrm{C}$ ), zapewniając w ten sposób możliwość odparowania LPG.

Pomiar wskaźników zewnętrznych silników na hamowni odbywał się metodą równoważenia obciążenia przy zachowaniu stałego przyspieszenia. Zaniechano powtarzania pomiarów, gdyż jak wykazało kilka prób, pomiary tego samego silnika nie różniły się między sobą powyżej $1 \%$.

\section{Wyniki badań i ich dyskusja}

Wyniki pomiarów poddano analizie, porównując oba układy zasilania w zakresie wartości momentu obrotowego przy 100-procentach stopnia zasilania. W celu zautomatyzowania procesu obróbki danych stworzono własne oprogramowanie obliczeniowe w pakiecie Matlab-Simulink, dodatek Guide [12, 22, 24, 30].

Oprogramowanie na podstawie wczytanych danych z pliku .txt każdego badanego silnika wyznacza kształt charakterystyk zewnętrznych i różnice w momencie obrotowym [\%] w odniesieniu do bezwymiarowej wartości prędkości obrotowej (rys. 3). Bezwymiarowość prędkości obrotowej zrealizowano w celu ujednolicenia skali odniesienia, mając na uwadze fakt, że jednostki napędowe mogą pracować w różnych zakresach prędkości roboczych.

Dodatkowo wyznaczane były wartości maksymalne mocy i momentu obrotowego, jak też współczynników elastyczności silnika i zapasu momentu obrotowego.

W dalszym etapie otrzymane wyniki poddano obróbce statystycznej, gdzie wyznaczono podstawowe parametry, tj.:

- średnią arytmetyczną (1),

- błąd standardowy (2)

- skośność (3)

- kurtozę (4).

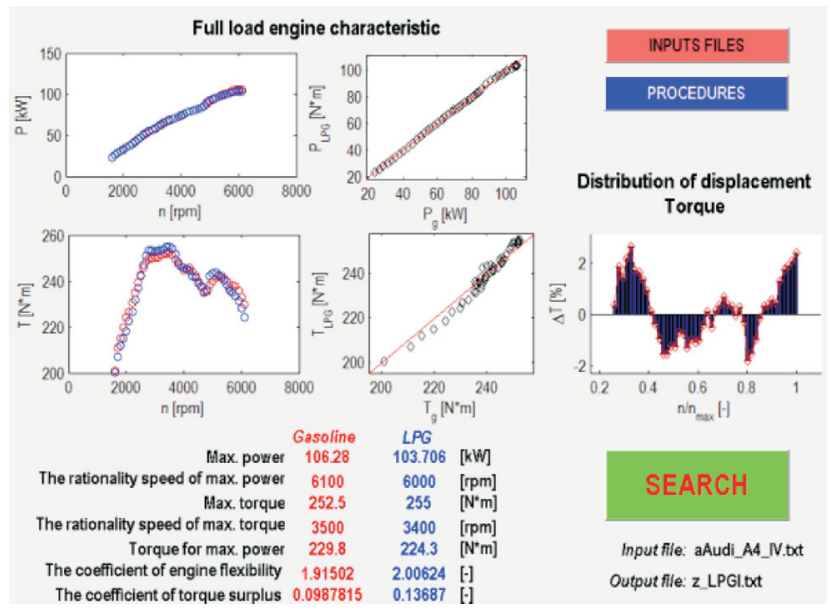

Fig. 3. The dialog box to distribution of displacement torque program (Matlab-Simulink, Guide addition)

Rys. 3. Panel komunikacyjny programu do wyznaczania odchyłek momentu obrotowego (Matlab-Simulink, dodatek Guide) 
The distribution showed left-sided asymmetry. The kurtosis exceeded 3.0 twice, which shows that the significant values focused around the average.

In the case of the II generation LPG system, the average deviation had slightly smaller values than in the previous case $(6.1 \%)$. The distribution was slightly right-sided with a 6.8 concentration indicating a thinning.

The lowest torque deviations were observed in the case of the IV generation LPG system (average 4.0\%). The distribution had a slight right-sided asymmetry, with the greatest thinning of all the tested examples - 15.4.

In spite of the fact, that the average value of torque deviation was the lowest from all the tested ones, the standard deviation exceeded the average value, which denotes a significant spread.

All average values of torque deviations guarantee the correctness of the assessment in the range of approx. 0.3 against the average.

Analyzing the torque deviations spread shown in Fig. 5, in each of the considered groups, engines characterized by a deviation exceeding $20 \%$ can be distinguished.

The biggest deviations, exceeding $20 \%$ occurred in Daewoo Nexia 1.5 MPi, fitted with the II generation LPG system (mixer with solenoid controlling constant gas flow). This condition may have been caused by insufficient reducerevaporator efficiency or the regulation settings.

Incorrect selection of the reducer-evaporator efficiency for engine fuel demand can cause gradual increase in the differences of torque values during the growing engine speed when full load engine characteristics is being determined. Mercedes-Benz W123 2.0 (Fig. 6) engine is a good example here (traditional carburetor engine, alternative fueling with the I generation LPG system). Another reason may be reduced flow to the mixer through the LPG valve.

Alternative volatile phase LPG system can significantly change the shape of the full load engine characteristics, as has been shown in Fig. 7.

b)

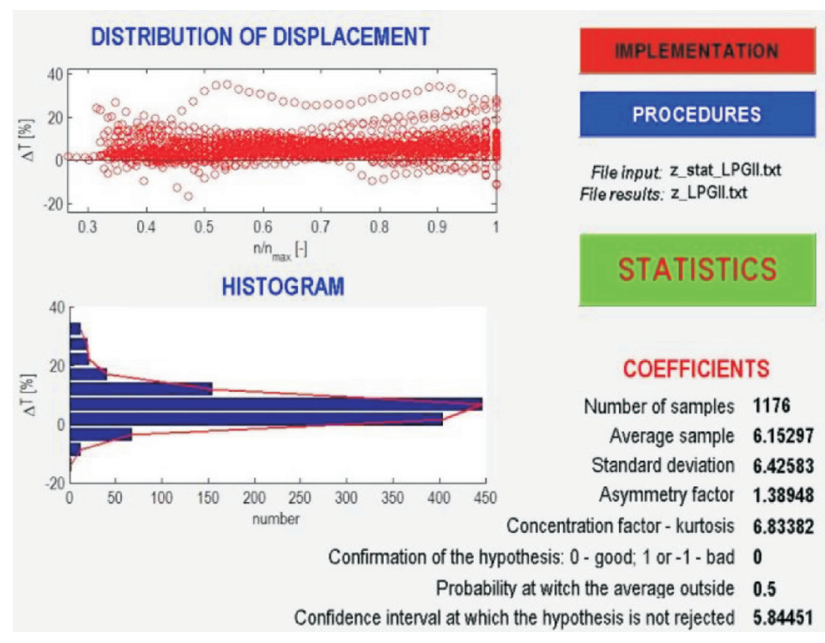

Wykorzystując dodatek Giude, stworzono kolejne oprogramowanie do wyznaczania statystyki rozkładu odchyłek momentu obrotowego poprzez opcję $t_{\text {test }}$ w pakiecie MatlabSimulink (rys. 4). W efekcie poza parametrami opisanymi zależnościami (1-4) wyznaczano prawdopodobieństwo równości wartości średnich, wyjścia poza zakres, jak też przedział ufności, przy którym hipoteza o równości średnich nie zostanie odrzucona.

W tabeli 2 podano wyniki obróbki statystycznej odchyłek momentu obrotowego przy obu rodzajach zasilania, w różnych grupach badawczych.

Największe różnice w wartościach odchyłek momentu obrotowego widoczne są przy zasilaniu LPG I generacji, średnio 6,3\%. Rozkład wykazuje asymetrię lewostronną. Wartość kurtozy dwukrotnie przekraczała 3,0, co wskazuje na znaczne skupienie wartości wokół średniej.

Dla LPG II generacji średnia odchyłka przyjmuje niewiele mniejszą wartość niż poprzednio i wynosi $6,1 \%$. Rozkład jest lekko prawostronny, o skupieniu 6,8 wskazującym na wyszczuplenie.

a)

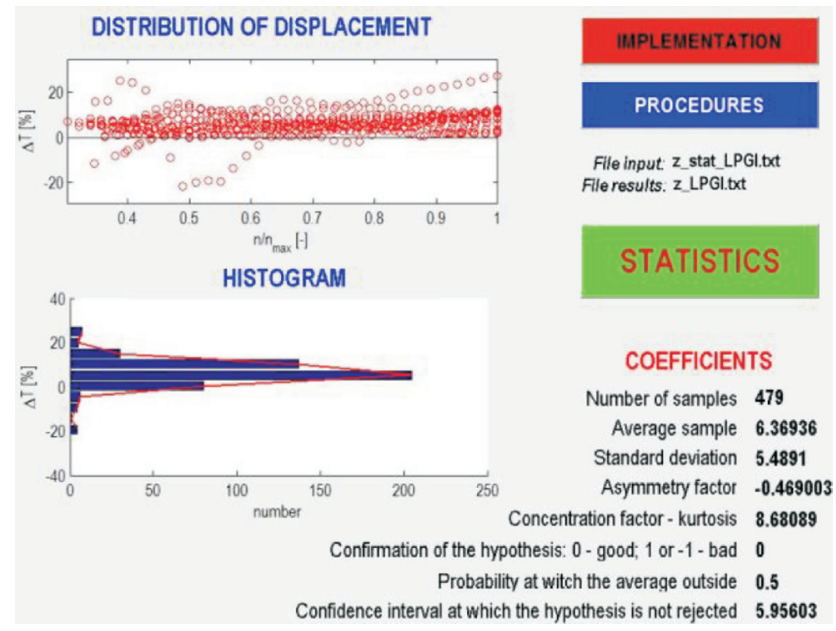

c)

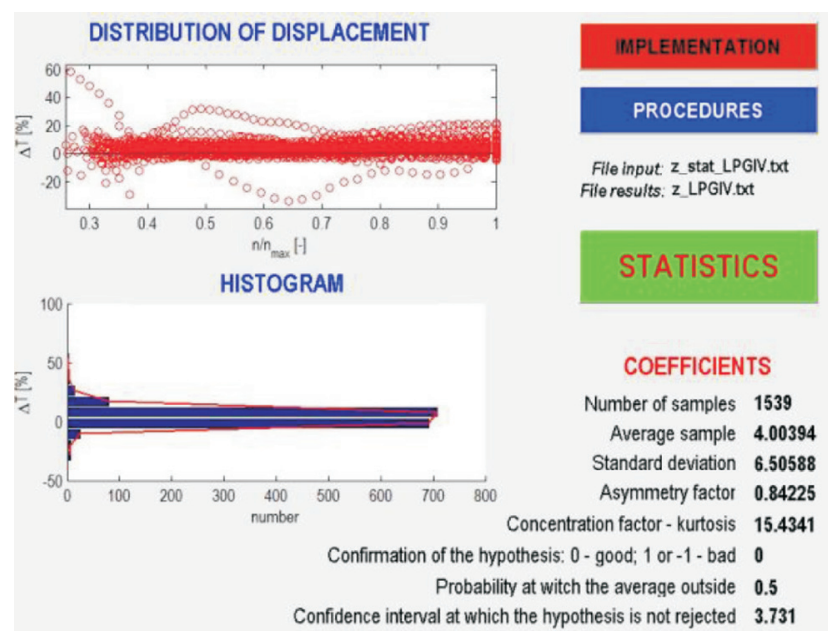

Fig. 4. The dialog box to statistical calculations program (Matlab-Simulink, Guide addition): a - LPG I, b - LPG II, c - LPG IV gen. Rys. 4. Panel komunikacyjny programu do obliczeń statystycznych (Matlab-Simulink, dodatek Guide): a - LPG I, b - LPG II, c-LPG IV gen. 
Table 2. Results of the statistical calculations for groups

Tabela. 2. Wyniki obliczeń statystycznych dla grup

\begin{tabular}{|l|c|c|c|}
\hline \multirow{2}{*}{ Parameter/parametr } & \multicolumn{2}{|c|}{ Displacement/przesunięcie } \\
\cline { 2 - 4 } & I gen. & II gen. & IV gen. \\
\hline Number of samples/liczba próbek & 479 & 1176 & 1539 \\
\hline Average sample [\%]/wartość średnia & 6.3694 & 6.1539 & 4.0039 \\
\hline Standard deviation/odchylenie standardowe & 5.4891 & 6.4258 & 0.5059 \\
\hline Bias/skośność & -0.4690 & 1.3895 & 0.8422 \\
\hline Kurtosis/kurtoza & 6.8834 & 6.8338 & 15.4341 \\
\hline Confirmation of the hypothesis/zgodność hipotezy & 0 & 0 & 0 \\
\hline $\begin{array}{l}\text { Probability at witch average outside/prawdopodobieństwo } \\
\text { wyjścia średniej poza zakres }\end{array}$ & 0.5 & 0.5 & 0.5 \\
\hline $\begin{array}{l}\text { Confidence interval at which the hypothesis is not rejected/ } \\
\text { przedziat ufności, przy którym hipoteza nie zostanie odrzucona }\end{array}$ & 5.9560 & 5.8445 & 3.7310 \\
\hline
\end{tabular}
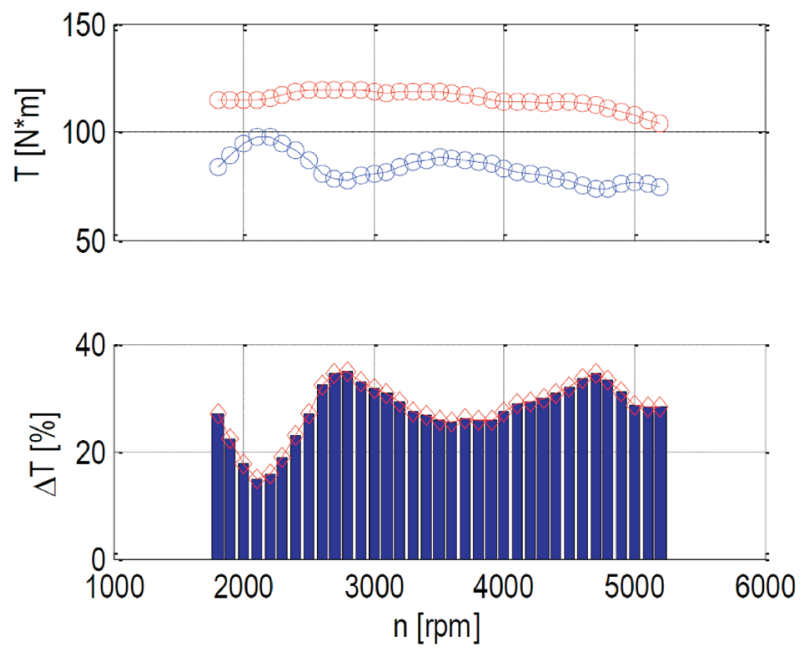

Fig. 5. Full load engine characteristic and displacement values of torque at both power systems Daewoo Nexia (red - gasoline, blue - LPG)

Rys. 5. Charakterystyka petnej mocy silnika oraz wartości odchyłek momentu obrotowego przy obu uktadach zasilania - Daewoo Nexia (czerwony - benzyna, niebieski-LPG)

The results pertain to the Ford Sierra 2.0 MPi engine, alternatively powered with the I generation LPG system (mixer with a mechanical valve regulating the gas flow). The maximum torque value occurs at the speed lower by $300 \mathrm{rpm}$ compared to gasoline fueling and then drops by $20 \%$, which influences the vehicle dynamics. However, the torque values indicate significant shortages of power for both fueling system variants.

In the case of the Honda Civic 1.4 MPi (Fig. 8) engine, alternatively powered with the IV generation LPG system (multi-point sequential injection of volatile phase) the application of LPG significantly lowered the torque values (at $3200 \mathrm{rpm}$ - approx. 25\%).

Determining the full load characteristics on the chassis dynamometer with load balancing results in a rapid load increase at the point defined as start of the measurement. The start of the measurement is defined through the device software, usually at vehicle speed of $50 \mathrm{~km} / \mathrm{h}$.

As a reaction to rapid (step) load increase, the fueling system can react in various ways. In the case of traditional (gasoline) fueling system, the injectors can extend the injec-
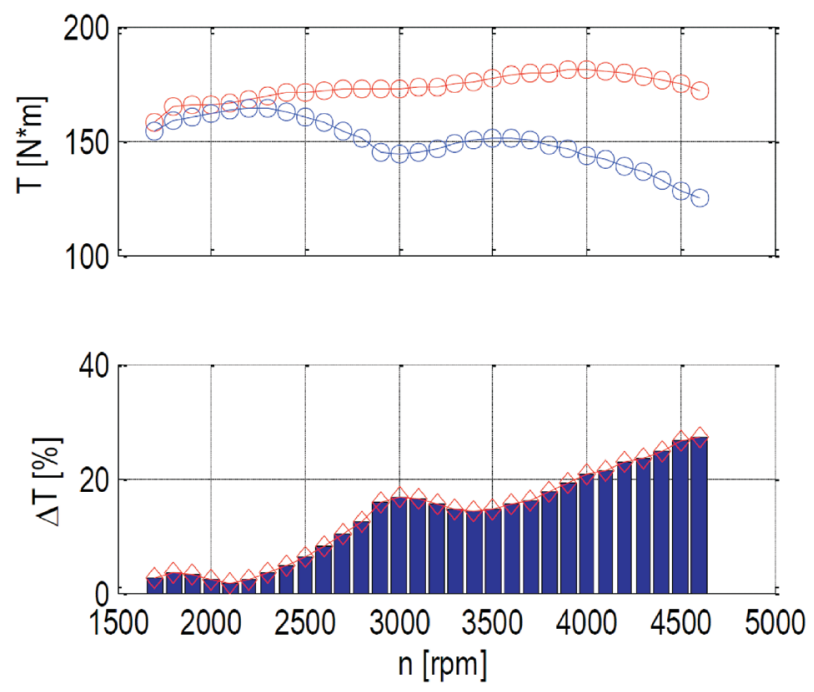

Fig. 6. Full load engine characteristic and displacement values of torque at both power systems - Mercedes W123 2.0 (red - gasoline, blue LPG)

Rys. 6. Charakterystyka petnej mocy silnika oraz wartości odchytek momentu obrotowego przy obu uktadach zasilania-Mercedes W123 2.0 (czerwony - benzyna, niebieski - LPG)

Najmniejsze wartości odchyłek momentu obrotowego odnotowano dla zasilania LPG IV generacji (średnio 4,0\%). Rozkład jest lekko asymetryczny prawostronnie, o największym wyszczupleniu spośród badanych - 15,4.

Pomimo że wartość średnia odchyłki momentu obrotowego w grupie LPG IV była najmniejsza ze wszystkich badanych, odchylenie standardowe przewyższyło wartość średnią, co świadczy o dużym rozrzucie.

Wszystkie wartości średnie odchyłek momentu obrotowego gwarantują poprawność wnioskowania w obrębie ok. 0,3 względem średniej.

Analizując rozrzut odchyłek momentu obrotowego przedstawiony na rys. 5, w każdej z rozpatrywanych grup można wyodrębnić jednostki napędowe, które charakteryzują się odchyłką przekraczają 20\%.

Największe odchyłki, przekraczające 20\%, stwierdzono dla silnika samochodu Daewoo Nexia 1.5MPi, alternatywnie zasilanego układem LPG II generacji (mieszalnikiem z elektrozaworem w sposób ciągły sterującym dopływem 

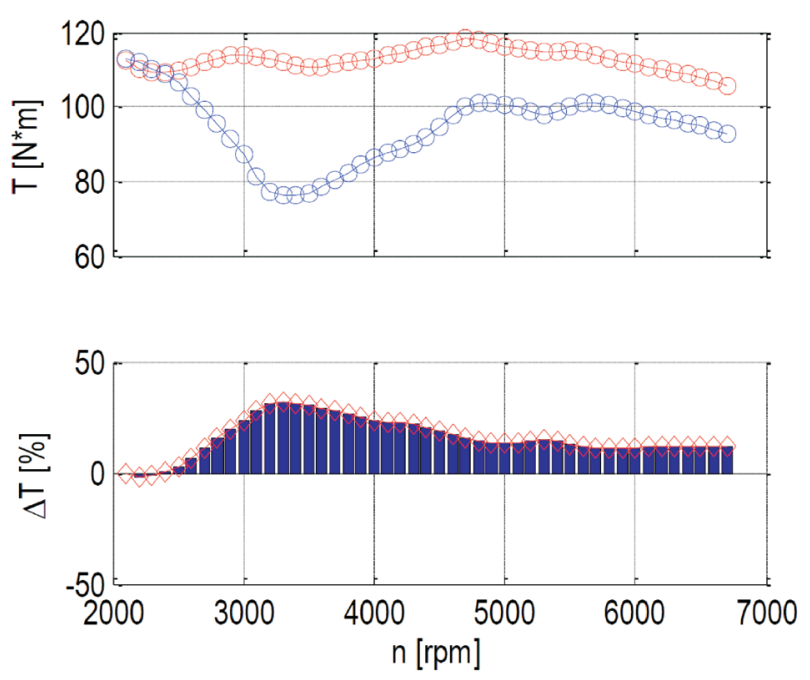

Fig. 7. Full load engine characteristic and displacement values of torque at both power systems - Ford Sierra 2.0 MPi (red - gasoline, blue LPG)

Rys. 7. Charakterystyka petnej mocy silnika oraz wartości odchytek momentu obrotowego przy obu uktadach zasilania - Ford Sierra 2.0 $M P i$ (czerwony - benzyna, niebieski-LPG)

tion time or additional dosage can be delivered. Both cases can have negatively influence the operation of the alternative fueling system. In the first case, extending the opening time after calculating the LPG injection time can result in a constant injector opening and a temporary system error. The second case, with post-injections of fuel with several 'small' doses causes the risk of LPG injectors operating outside their opening time range. The BMW E43 323i engine is a good example - traditionally fitted with a multi-point injection and alternatively - with the IV generation LPG system (Fig. 9).
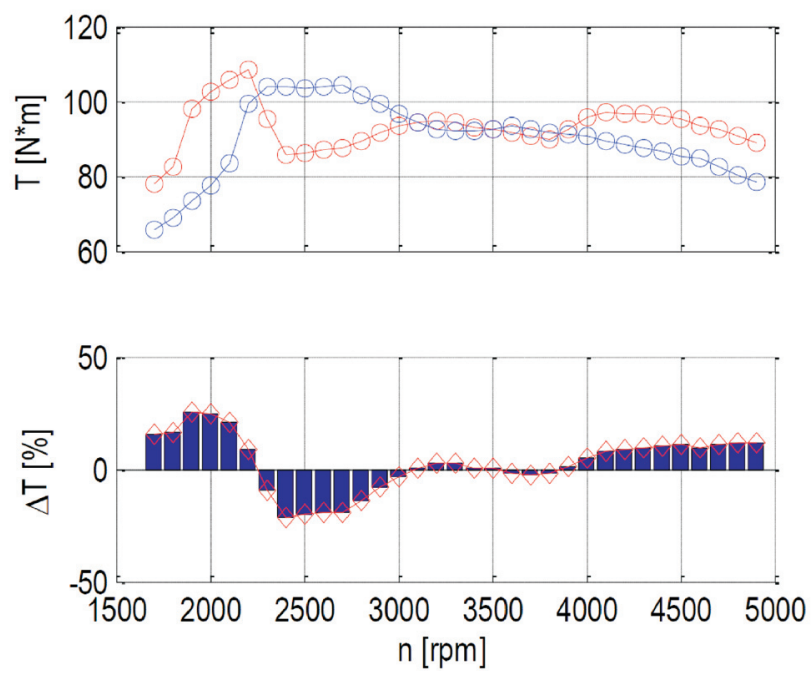

Fig. 8. Full load engine characteristic and displacement values of torque at both power systems - Honda Civic 1.4 MPi (red - gasoline, blue LPG)

Rys. 8. Charakterystyka petnej mocy silnika oraz wartości odchyłek momentu obrotowego przy obu układach zasilania - Honda Civic 1.4 MPi (czerwony - benzyna, niebieski-LPG) gazu). Mogło to wynikać z niedostatecznej wydajności reduktora-parownika lub nastaw regulacyjnych.

Nieodpowiedni dobór wydajności reduktora-parownika do zapotrzebowania silnika na paliwo może skutkować stopniowym narastaniem różnic $\mathrm{w}$ wartościach momentu obrotowego w miarę zwiększania prędkości obrotowej przy wyznaczaniu charakterystyki pełnej mocy. Jako przykład można przedstawić silnik pojazdu Mercedes W123 2.0 (rys. 6) klasycznie zasilanego przez gaźnik, alternatywnie układem LPG I generacji. Powodem może być również zbytnie zmniejszenie przepływu na zaworze doprowadzającym LPG do mieszalnika.

Alternatywny układ zasilania LPG w fazie lotnej może znacząco zmienić również kształt charakterystyki pełnej mocy, co przedstawiono na rys. 7.

Wyniki dotyczą silnika pojazdu Ford Sierra 2.0 MPi alternatywnie zasilanego układem LPG I generacji (mieszalnikiem z mechanicznym zaworem regulującym dopływ gazu). Wartość maksymalna momentu obrotowego występuje przy prędkości obrotowej niższej o $300 \mathrm{obr} / \mathrm{min}$ niż przy zasilaniu benzyną, po czym spada o $20 \%$, co wpływa na dynamikę pojazdu w ruchu. Wartości momentu obrotowego wskazują jednak na znaczne niedomagania jednostki napędowej dla obu wariantów układów zasilania.

W odniesieniu do silnika pojazdu Honda Civic 1.4 MPi (rys. 8), zasilanego alternatywnie układem LPG IV generacji (wielopunktowy sekwencyjny wtrysk fazy lotnej), wykorzystanie gazu znacznie obniżyło wartości momentu obrotowego, przy $3200 \mathrm{obr} / \mathrm{min}$ - ok. 25\%.

Wyznaczanie charakterystyki prędkościowej pełnej mocy na hamowni podwoziowej działającej $\mathrm{z}$ równoważeniem obciążenia wiąże się z gwałtownym wzrostem obciążenia w punkcie określanym jako start pomiarów. Start pomiaru ustala się na poziomie oprogramowania urządzenia; przeważnie jest to $50 \mathrm{~km} / \mathrm{h}$ w odniesieniu do prędkości jazdy.
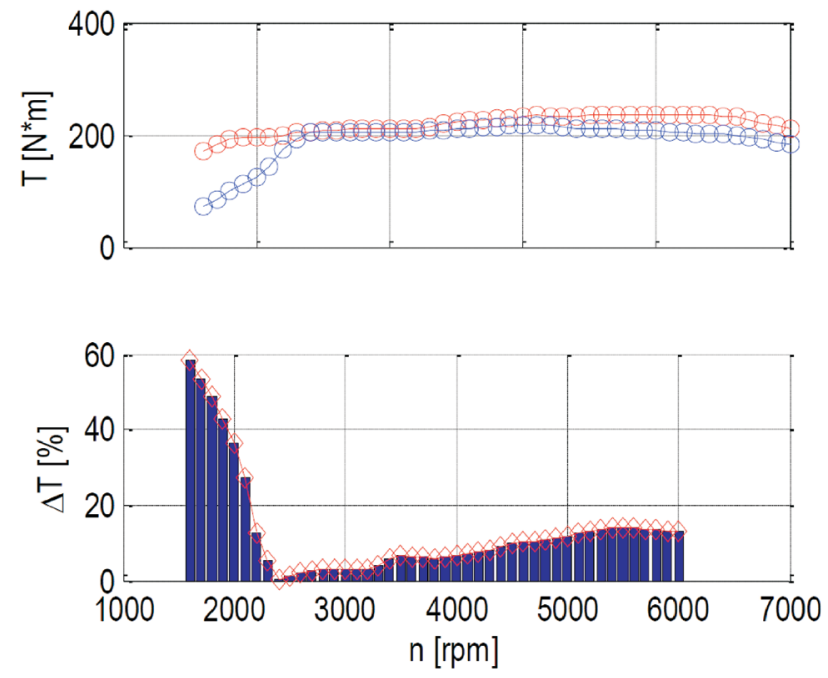

Fig. 9. Full load engine characteristic and displacement values of torque at both power systems - BMW E36 323i (red - gasoline, blue - LPG) Rys. 9. Charakterystyka petnej mocy silnika oraz wartości odchyłek momentu obrotowego przy obu uktadach zasilania - BMW E36 323i (czerwony - benzyna, niebieski-LPG) 


\section{Conclusions}

In the research, the differences in the full load characteristics were investigated of engines additionally fitted with alternative LPG systems. The comparison was performed at the time when the engines were already fitted with alternative fueling systems in the case of which the installation of additional parts could influence the external indicators. Values given in the manufacturer specifications for new vehicles were not presented because the tested units had already been in service. The population was divided into three groups according to the LPG fueling system generation. 86 units were subjected to analysis. The performed analysis rendered what follows:

1. The lowest difference in torque deviations, at a level of approx. 4\% was observed in the IV generation LPG group. The I and II generation differed on average by approx. 6\% due to similar fueling system architecture.

2. In the case of IV generation LPG fueling, the standard error that exceeded its average value was observed, which has proven a significant spread.

3. The distribution of torque deviations in each case achieved minimum asymmetry, whereas the concentration around the average, determined by the value of kurtosis above 3.0 indicated a thinning.

4. The spread analysis of the deviations as a function of the dimensionless speed, except the I generation LPG, showed their decrease in the medium engine speed range.

5. The correct engine adaptation for alternative LPG fueling takes place when the wide-open throttle characteristics does not differ more than 5\% from the traditional (gasoline) fueling. This criterion is met by IV generation LPG systems.

6. In mixer-based systems, proper selection of the actuators and efficiency adjustment are required.

\section{Nomenclature/Skróty i oznaczenia}

$\mathrm{HC}$ hydrocarbon/weglowodory

$\mathrm{CO}$ carbon monoxide/tlenek wegla

LPG Liquefied Petroleum Gas/skroplony gaz ropopochodny

I generation LPG LPG vapour fueling phase by mixing with periodic flow control/zasilanie LPG $w$ fazie lotnej przez mieszalnik z okresowa regulacja przeptywu

II generation LPG LPG vapour fueling phase by mixing with continuos flow control/zasilanie LPG w fazie lotnej przez mieszalnik z ciagła regulacji przeptywu

IV generation LPG LPG vapour fueling phase by impulse injectors/zasilanie LPG $w$ fazie lotnej przez wtryskiwacze pośrednie

arithmetic average/wartość średnia

$\mathrm{Sb} \quad$ estimator of standard deviation/btad standardowy

Ad bias/skośność

K kurtosis/kurtoza

$\mathrm{t}_{\text {test }} \quad$ returns the decision to test zero hypothesis that the data in the study population come from a normal distribution with a mean and unknown variance/zwraca decyzje testu dla hipotezy zerowej, że dane w badanej populacji pochodza z rozktadu normalnego o pewnej średniej i nieznanej wariancji
$\mathrm{Na}$ gwałtownie (skokowo) rosnące obciążenie układ zasilania może zareagować w różny sposób. Dla klasycznego (benzynowego) układu zasilania wtryskiwacze mogą wydłużyć czas wtrysku lub podać dodatkowe dawki. Oba przypadki mogą negatywnie wpłynąć na działanie alternatywnego układu zasilania. W pierwszym przypadku wydłużenie czasu otwarcia po przeliczeniu na czas wtrysku LPG może skutkować ciągłym otwarciem wtryskiwacza i chwilowym błędem układu. Drugi przypadek z dotryskiem paliwa kilkoma „małymi” dawkami powoduje, iż wtryskiwacze LPG mogą znaleźć się poza zakresem czasów otwarcia, w którym mogą się otwierać. Jako przykład można wskazać silnik BMW E43 323i klasycznie zasilany wtryskiem wielopunktowym, alternatywnie układem LPG IV generacji (rys. 9).

\section{Podsumowanie}

W badaniach analizowano różnice w charakterystykach prędkościowych pełnej mocy silników benzynowych wyposażonych dodatkowo w alternatywne układy zasilania LPG. Porównanie przeprowadzono wtedy, gdy silniki były już wyposażone w alternatywne układy zasilania, gdzie zabudowa dodatkowych podzespołów mogła mieć wpływ na wartości wskaźników zewnętrznych. Nie odnoszono się do wartości podawanych w instrukcjach fabrycznych pojazdów nowych, gdyż badane jednostki napędowe były już w eksploatacji. Populację podzielono na 3 grupy stosownie do generacji układów zasilania LPG w fazie lotnej. Analizie poddano 86 jednostek napędowych. Przeprowadzona analiza pozwala stwierdzić:

1. Najmniejszą różnicę w odchyłkach momentu obrotowego wynoszącą ok. 4,0\% odnotowano w grupie LPG IV generacji, pozostałe, tj. I i II generacj z uwagi na zbliżony układ zasilani różnią się średnio ok. 6\%.

2. Przy zasilaniu LPG IV odnotowano wartość błędu standardowego przewyższającą wartość średnią, co świadczy o dużym rozrzucie.

3. Rozkład odchyłek momentu obrotowego we wszystkich przypadkach uzyskiwał minimalną asymetrię, z kolei skupienie wokół średniej określone wartością kurtozy pow. 3,0 wskazywało na wyszczuplenie.

4. Analiza rozrzutu odchyłek w funkcji bezwymiarowej prędkości, poza układem LPG I gen., wykazała ich zmniejszanie w zakresie prędkości obrotowych średnich.

5.Za poprawną adaptację silnika do zasilania alternatywnego LPG należy uznać układ, którego charakterystyka pełnej mocy nie różni się średnio więcej niż 5\% od zasilania klasycznego (benzynowego). Kryterium to w dużej mierze spełniają układy LPG IV generacji.

6. W układach mieszalnikowych konieczny jest poprawny dobór podzespołów wykonawczych połączony z regulacja wydajności, w przeciwnym razie uwidoczni się problem spadku momentu obrotowego sięgający w niektórych przypadkach $30 \%$. 


\section{Bibliography/Literatura}

[1] Aleiferis P.G., van Romunde Z.R.: An analysis of spray development with iso-octane, $\mathrm{n}$-pentane, gasoline, ethanol and n-butanol from a multi-hole injector under hot fuel conditions. Fuel 2013, 105, pp. 143-168.

[2] Aleiferisa P.G., Serras-Pereiraa J., Augoyea A., Daviesb T.J., Cracknellb R.F., Richardsonc D.: Effect of fuel temperature on in-nozzle cavitation and spray formation of liquid hydrocarbons and alcohols from a real-size optical injector for directinjection spark-ignition engines. Int. J. Heat Mass Transfer 2010, 53 (21-22), pp. 4588-4606.

[3] Arslana O., Kosea R., Ceylana N.: Experimental Analysis of Consumption and Exhaust Emissions of Gasoline and LPG in Car Engines Under Cold Climatic Conditions. Energ. Source. P-A:R.U.E.E. 2010, 33 (3), pp. 244-253.

[4] Bhale P.V., Ardhapurkar P.M., Deshpande N.V.: Experimental investigations to study the comparative effect of LPG and gasoline on performance and emissions of SI engine. Proceedings of the 2005 Spring Technical Conference of the ASME Internal Combustion Engine Division 2005, pp. 289-294.

[5] Cho S., Min K.: Injector control logic for a liquid-phase liquid petroleum gas injection engine. P. I. Mech. Eng. D-J. Aut. 2004, 218 (D1), pp. 71-79.

[6] Gumus M.: Effects of volumetric efficiency on the performance and emissions characteristics of adual fueled (gasoline and LPG) spark ignition engine. Fuel Process. Technol. 2011, 92, pp. 1862-1867.

[7] Hansub S., Kangyoon L., Lamhoon Ch., Myoungho S.: A study on the injection characteristics of a liquid-phase liquefied petroleum gas injector for air-fuel ratio control. P. I. Mech. Eng. D-J. Aut. 2005, 219 (8), pp. 1037-1046.

[8] Jang C., Kim S., Choi S.: Experimental and analytical study of the spray characteristics of an intermittent air-assisted fuel injector. Atomization Spays 2000, 10 (2), pp. 199-217.

[9] Kakuhou A.: LIF visualization of in-cylinder mixture formation in a direct-injection SI engine, $4^{\text {th }}$ International Symposium COMODIA 98, Kyoto 1998, Japan.

[10] Kim J., Choi K., Myung Ch., Park S.: Experimental evaluation of engine control strategy on the time resolved THC and nanoparticle emission characteristics of liquid phase LPG direct injection (LPG-DI) engine during the cold start, Fuel Process. Technol. 2013, 106, pp. 166-173.

[11] Kitae Y., Jungseo P., Choongsik B., Jeongnam P., Sungkun K.: Anti-vapor Lock of a Top-Feed Injector for a Liquefied Petroleum Gas Liquid-Phase Injection Engine. Energ. Fuel. 2009, 23 (2), pp. 876-883.

[12] Lagarias J.C., Reeds J.A., Wright M.H., Wright P.E.: Convergence Properties of the Nelder-Mead Simplex Method in Low Dimensions. SIAM J. Optimiz. 1998, 9 (1), pp. 112-147.

[13] Lekkas T.D., Kalligeros S., Zannikos F., Stournas S. et al.: Impact of gasoline quality on engine performance and emissions. P. Inter. Conf. Environ. Sci. Technol. 2003, pp. 340-345.

[14] Liu Y., Helfand G.E.: The Alternative Motor Fuels Act, alternative-fuel vehicles, and greenhouse gas emissions. Transport. Res. A-Pol. 2009, 43, pp. 755-764.

Dariusz Szpica, DEng. - doctor in the Faculty of Mechanical Engineering at Bialystok University of Technology.

Dr inż. Dariusz Szpica - adiunkt na Wydziale Mechanicznym Politechniki Białostockiej.

email:d.szpica@pb.edu.pl
[15] Movahednejad E., Ommi F., Nekofar K.: Experimental Study of Injection Characteristics of a Multi-hole port injector on various Fuel Injection pressures and Temperatures. EPJ Web of Conferences 2013, 45, p. 5.

[16] Murilloa S., Migueza J.L., Porteiroa J., Lopez-Gonzalezb L.M., Granadaa E., Morana J.C., Paza C.: Exhaust Emissions from Diesel, LPG, and Gasoline Low-power Engines. Energ. Source. P-A:R.U.E.E. 2008, 30 (12), pp. 1065-1073.

[17] Oliveira Panão M.R., Moreira A.L.N., Durao D.F.G.: Statistical analysis of spray impact to assess fuel mixture preparation in IC engines. Fuel Process. Technol. 2013, 107, pp. 64-70.

[18] Oliveira Panão M.R, Moreira A.L.N.: Flow characteristics of spray impingement in PFI injection systems. Exp. Fluids 2005, 39, pp. 364-374.

[19] Park K.: Behavior of liquid LPG spray injecting from a single hole nozzle. Int. J. Aut. Technol. 2005, 6 (3), pp. 215-219.

[20] Senda J., Yamaguchi M., Tsukamoto T. et al.: Characteristic of spray injected from gasoline injector. JSME Int. J. B-FLUID. T. 1994, 37 (4), pp. 931-936.

[21] Serras-Pereiraa J., Aleiferisa P.G., Walmsleyb H.L., Daviesb T.J., Cracknellb R.F.: Heat flux characteristics of spray wall impingement with ethanol, butanol, iso-octane, gasoline and E10 fuels. Int. J. Heat Fluid Flow 2013, 44, pp. 662-683.

[22] Shampine L.F., Reichelt M.W.: The MATLAB ODE Suite, SIAM J. Sci. Comput. 1997, 18, pp. 1-22.

[23] Sim H., Lee K., Chung N. et al.: Experimental analysis of a liquid-phase liquefied petroleum gas injector for a heavyduty engine. P. I. Mech. Eng. D-J. Aut. 2004, 218 (D7), pp. 719-727.

[24] Smith, S.T.: Matlab Advanced GUI Development; Dog Ear Publishing: Indianapolis, 2006.

[25] Szpica D., Czaban J.: Ocena stosowalności LPG jako paliwa w silnikach trakcyjnych: [rozdz.], Silniki gazowe: wybrane zagadnienia, pod red. Adama Dużyńskiego, Wydaw. Politechniki Częstochowskiej 2010, s. 504-513.

[26] Szpica D., Czaban J.: Porównanie klasycznych i alternatywnych układów zasilania silników na podstawie charakterystyk zewnętrznych, Przegląd Mechaniczny 2009, 7/8, s. 26-31.

[27] Szpica D., Czaban J.: Ocena wskaźników zewnętrznych i operacyjnych silników zasilanych LPG, Silniki Spalinowe 2010, 3, s. 68-75.

[28] Szpica D., Czaban J.: Zależność Leidemana a współczesne konstrukcje silników spalinowych, Przegląd Mechaniczny 2010, 6, s. 24-29.

[29] Szpica D., Piwnik J., Sidorowicz M.: The motion storage characteristics as the indicator of stability of internal combustion engine - receiver cooperation, Mechanika 2014, 20(1), pp. 108-112.

[30] Yang W.Y., Cao W., Chung T.S., Morris J.: Applied numerical methods using MATLAB; John Wiley \& Sons Inc, Hoboken, New Jersey, 2005.

[31] Zhang J., Yao S., Patel H., Fang T.: An experimental study on gasoline direct-injection spray and atomization characteristics of alcohol fuels and isooctane. Atomization Sprays 2011, 21, pp. 363-374.

Jarosław Czaban, DEng. - doctor in the Faculty of Mechanical Engineering at Bialystok University of Technology.

Dr inż. Jarostaw Czaban - adiunkt na Wydziale Mechanicznym Politechniki Białostockiej.

email: j.czaban@pb.edu.pl

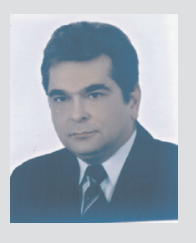

